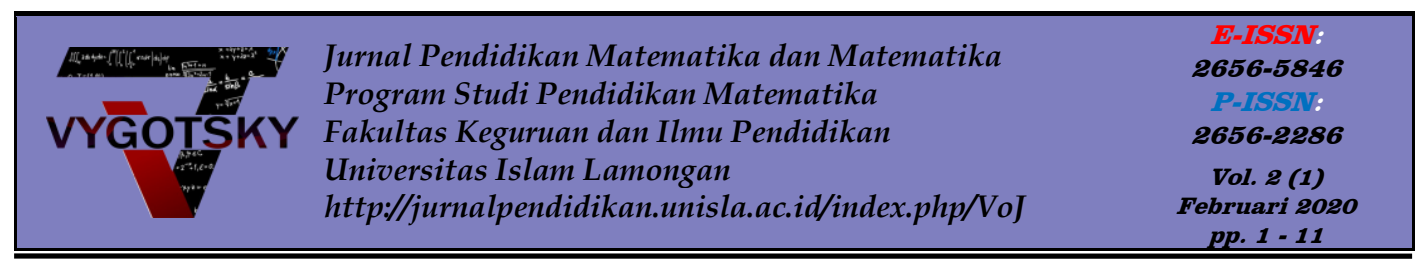

\title{
ANALISIS KEMAMPUAN REPRESENTASI MATEMATIS SISWA DALAM MENYELESAIKAN SOAL ALJABAR
}

\author{
(ANALYSIS OF STUDENT'S MATHEMATICAL REPRESENTATITON \\ ABILITIES IN SOLVING ALGEBRA PROBLEMS)
}

\author{
Fitrianingrum Fitrianingrum ${ }^{1}$, Mochamad Abdul Basir ${ }^{2}$ \\ 1Universitas Islam Sultan Agung, fitrianingrum10@std.unissula.ac.id
}

${ }^{2}$ Universitas Islam Sultan Agung, abdulbasir@unissula.ac.id

\begin{tabular}{l}
\hline \hline Info Artikel \\
\hline Received Jan 06, 2020 \\
Revised Feb 11, 2020 \\
Accepted Feb 24, 2020 \\
\end{tabular}

\section{Kata Kunci:}

Kemampuan Representasi, Program Linear, Penyelesaian Masalah

\begin{abstract}
This qualitative study aims to determine the ability of student representation in solving algebraic. This research was conducted at Sultan Agung 3 Islamic High School Semarang. The method use is descriptive analysis with data collection techniques such as test and documentation the research subject is students XI MIPA 2 2019/2020 school year. The result data analysis showed that: (1) student visual representation ability was in moderate category with a percentage of $85,08 \%$. (2) for the percentage of the acquisition of symbolic representations of $91,2 \%$ this generally shows that students are ready skilled at making mathematical model (3) while the percentage of verbal representations of $67,54 \%$ is classified as high.
\end{abstract}

\begin{tabular}{l}
\hline Abstrak \\
Penelitian kualitatif ini bertujuan untuk mengetahui \\
kemampuan representasi siswa dalam \\
menyelesaikan soal aljabar. Penelitian ini \\
dilakukan di SMA Islam Sultan Agung 3 \\
Semarang. Metode penelitian yang digunakan \\
adalah analisis deskriptif dengan teknik \\
pengumpulan data berupa tes dan dokumentasi. \\
Subjek penelitian adalah siswa kelas XI MIPA 2 \\
Tahun Pelajaran 2019/2020. Hasil analisis data \\
menunjukkan: (1) kemampuan representasi visual \\
siswa dalam kategori sedang dengan presentase \\
sebesar 85,08\%. (2) untuk presentase kemampuan \\
representasi simbolik sebesar 91,22\% hal ini secara \\
umum menunjukkan bahwa siswa sudah terampil \\
membuat model matematika. (3) sedangkan \\
presentase kemampuan representasi verbal \\
sebesar 67,54\% tergolong dalam kategori tinggi.
\end{tabular}

Copyright $\odot 2020$ Vygotsky: Jurnal Pendidikan Matematika dan Matematika. All right reserved 


\section{PENDAHULUAN}

Matematika merupakan mata pelajaran yang pasti diajarkan pada setiap jenjang pendidikan mulai dari SD, SMP, SMA. Berdasarkan Permendiknas Nomor 22 Tahun 2006 tentang Standar Isi Mata Pelajaran Matematika, tujuan pembelajaran matematika adalah siswa dapat mengkomunikasikan gagasan dengan simbol, tabel, diagram, atau media lain untuk memperjelas keadaan atau masalah. Dalam menyelesaikan matematika siswa menggunakan bahasa yang matematis dan mudah dipahami dan dipersiapkan untuk dapat mengembangkan pemikiran yang inovatif dan kreatif. Siswa dalam pembelajaran di sekolah dilatih melakukan penalaran, artinya siswa aktif bernalar dalam pembelajaran di sekolah, memperdalam pemahaman terhadap konsep-konsep matematika (Kusmaryono, 2016). Selain itu, dalam pembelajaran matematika sangat perlu adanya kecakapan matematis. Seperti yang diungkapkan oleh (Nelli, Yusmin, \& Sayu, n.d.), "minimal ada lima kecakapan matematis yang perlu dipunyai seorang siswa agar sukses belajar matematika. Dari kelima kecakapan matematis, salah satunya yaitu strategic competence (kompetensi strategis), sebagai point penting untuk seorang siswa mencapai kesuksesan belajar matematika. Lebih lanjut (Nelli et al., n.d.) menyatakan,"kompetensi strategis mengacu pada kemampuan untuk merumuskan, menyajikan, dan menyelesaikan masalah matematika." Dalam kompetensi strategis tersebut, representasi menjadi salah satu hal penting. Bagaimana seorang siswa dapat menyajikan suatu konsep matematika yang kemudian dapat menjadi kemudahannya dalam belajar matematika. (Sulatri, Marwan, \& Duskri, 2017) menambahkan bahwa representasi merupakan dasar bagi seorang siswa dalam memahami dan menggunakan ide-ide matematika. Dengan demikian perlu dikaji lebih mendalam tentang kemampuan representasi matematis siswa.

Kemampuan representasi awalnya masih dipandang sebagai bagian dari kemampuan komunikasi matematis. Hal ini terlihat dalam (Tyas \& Sujadi, 2016) yang awalnya hanya merekomendasikan empat kompetensi dasar yaitu Pemecahan Masalah, Komunikasi, Koneksi, dan Penalaran. Namun setelah disadari bahwa kemampuan representasi matematis merupakan hal yang selalu ada ketika seseorang mempelajari matematika pada semua tingkatan/level pendidikan maka representasi dipandang sebagai komponen yang penting sehingga perlu mendapatkan perhatian. (Fariz, Gusrayani, \& Isrok'atun, 2006), mengemukakan hasil wawancaranya dengan guru yang hasilnya bahwa guru jarang memperhatikan representasi matematis, khususnya bentuk representasi visual diberikan kepada siswa hanya sebagai pelengkap dalam penyampaian materi. Sehingga representasi matematis layak ditekankan dan dimunculkan dalam proses pengajaran matematika di sekolah. (Wijaya, 2018) Kemampuan representasi matematis merupakan salah satu kemampuan yang berhubungan dengan kemampuan pemahaman matematis. Representasi merupakan hal utama dalam membangun pengetahuan dan pemahaman siswa dalam mempelajari suatu konsep 
matematika. Sesuai dengan representasi matematis sangat penting karena dapat membantu siswa dalam mengorganisasikan pemikiran mereka dalam menyelesaikan masalah atau soal. Pentingnya representasi matematis tersebut juga sesuai dengan (Wijaya, 2018) yang menyatakan bahwa representasi adalah pusat untuk belajar matematika. Siswa dapat mengembangkan dan memperdalam pemahaman mereka tentang konsep matematika dan hubungan yang mereka buat, membandingkan, dan menggunakan representasi yang bermacam-macam. Menurut (Wijaya, 2018), representasi adalah suatu bentuk interpretasi dari pemikiran siswa terhadap suatu masalah yang digunakan sebagai alat bantu dalam mencari solusi dari permasalahan tersebut. Bentuk representasi yang muncul dari setiap siswa tentu bervariasi. Representasi bermacam macam dapat berupa kata-kata, tulisan, gambar, tabel, grafik, simbol matematika, dan sebagainya sesuai kemampuan siswa. (Fariz et al., 2006) menyatakan bahwa "kemampuan representasi dapat menbantu siswa dalam belajar konsep-konsep matematika yang dipelajari dan keterkaitannya; untuk mengkomunikasikan ide-ide matematika siswa; untuk lebih mengenal koneksi diantara konsep-konsep matematika; ataupun menerapkan matematika pada permasalahan matematik realistik melalui pemodelan. Kemudian (Huda, Musdi, \& Nari, 2019) juga mengatakan bahwa representasi menjadi pedoman bagi siswa dalam memahami dan menerapkan konsep-konsep matematika.

Ulandari et al. (n.d.) mengungkapkan bahwa representasi adalah pernyataan dari ide matematis yang ditunjukkan siswa sebagai model atau bentuk pengganti dari suatu kondisi masalah yang digunakan untuk mencari solusi dari suatu masalah yang sedang dihadapinya sebagai hasil dari interpretasi pikirannya. Representasi merupakan salah satu konsep psikologi yang digunakan dalam pendidikan matematika untuk menjelaskan beberapa peristiwa penting tentang cara berpikir siswa (Rahmawati, Hudiono, \& Nursangaji, n.d.). Lebih lanjut, (Hijriani, Rahardjo, \& Rahardi, 2018) mengemukakan bahwa representasi merupakan konfigurasi dari gambar, atau objek nyata yang merepresentasikan sesuatu yang lain. Representasi adalah bentuk interpretasi pemikiran siswa terhadap suatu masalah, yang digunakan sebagai alat bantu untuk menemukan solusi dari masalah tersebut (Kholiqowati, Sugiarto, \& Hidayah, 2016).

Villegas et al. (2009) membagi representasi matematis menjadi tiga bentuk yaitu representasi verbal, representasi gambar, dan representasi simbolik. Penjelasan dari ketiga bentuk representasi yang dijabarkan oleh (Villegas et al., 2009), sebagai berikut:

1. Representasi verbal pada dasarnya mencakup soal cerita yang dijadikan sebagai suatu pernyataan yang dijelaskan, baik secara teks tertulis atau diucapkan

2. Representasi gambar terdiri dari gambar, diagram, atau grafik, dan lainnya

3. Representasi simbolik adalah representasi yang dapat berupa 
membuat suatu bilangan, operasi dan tanda penghubung, simbol aljabar, operasi matematika dan relasi, angka, dan berbagai jenis lain.

Menurut Dahlan \& Juandi (2011) indikator beserta bentuk-bentuk operasional yang digunakan dalam menilai kemampuan representasi matematis siswa secara lengkap sebagai berikut :

Tabel 1. Indikator Kemampuan Representasi Matematis

\begin{tabular}{|c|c|c|}
\hline No & Representasi & Bentuk Operasional \\
\hline 1. & $\begin{array}{l}\text { Visual berupa } \\
\text { a. Grafik, diagram } \\
\text { atau tabel }\end{array}$ & $\begin{array}{l}\text { - Menyajikan kembali data atau } \\
\text { informasi kedalam grafik, } \\
\text { diagram atau tabel } \\
\text { - Memanfaatkan represenatsi } \\
\text { visual untuk memecahkan } \\
\text { masalah }\end{array}$ \\
\hline & b. Gambar & $\begin{array}{l}\text { - Membuat pola geometri } \\
\text { - Membuat bangun geometri } \\
\text { untuk menerjemahkan masalah } \\
\text { dan memfasilitasi masalahnya }\end{array}$ \\
\hline 2. & $\begin{array}{lr}\text { Simbolik } & \text { (persamaan } \\
\text { atau } & \text { ekspresi } \\
\text { matematis) } & \end{array}$ & $\begin{array}{l}\text { - Membuat persamaan, model } \\
\text { matematika atau representasi } \\
\text { dari representasi lain yang } \\
\text { diberikan } \\
\text { - Membuat konjektur dari suatu } \\
\text { pola hubungan } \\
\text { - Menyelesaikan masalah dengan } \\
\text { melibatkan ekpresi matematika }\end{array}$ \\
\hline 3. & $\begin{array}{l}\text { Verbal (kata-kata atau } \\
\text { teks tertulis) }\end{array}$ & $\begin{array}{l}\text { - Membuat situasi masalah } \\
\text { berdasarkan data atau } \\
\text { representasi yang diberikan } \\
\text { - Menuliskan interpretasi dari } \\
\text { suatu representasi } \\
\text { - Menuliskan langkah-langkah } \\
\text { pemecahan masalah } \\
\text { matematika secara tertulis } \\
\text { - Menyusun narasi sesuai dengan } \\
\text { representasi yang ditampilkan } \\
\text { - Menyelesaikan menggunakan } \\
\text { kata-kata atau secara tertulis }\end{array}$ \\
\hline
\end{tabular}

Erdy Poernomo (2014) dalam penelitiannya yang berjudul "Pengaruh Pembelajaran Kooperatif Strategi Think-Talk-Write Menggunakan Masalah Kontekstual Terhadap Peningkatan Kemampuan Representasi Matematis Siswa", menemukan bahwa kemampuan representasi matematis siswa masih 
tergolong rendah. Dari tiga indikator representasi menurut Villegas dalam penelitian ini, representasi dalam bentuk simbol dan verbal lebih tinggi dari pada representasi dalam bentuk gambar.

Materi aljabar merupakan materi yang masih dianggap sulit pada siswa SMA. Pada penelitian ini, materi yang dipilih adalah aljabar lebih khususnya program linear. Program linear merupakan materi yang dapat dibuat soal kontekstual atau soal cerita. Dimana pada saat menyelesaikan soal cerita siswa perlu pemahaman yang baik agar dapat menemukan solusi. Pada materi program linear soal cerita juga dibutuhkan kemampuan representasi yang baik dan benar, bisa dalam menuliskan model matematika, grafik serta membuat persamaan.

Berdasarkan uraian diatas, peneliti tertarik untuk melakukan penelitian guna mengetahui kemampuan representasi matematis siswa dalam menyelesaikan soal aljabar di kelas XI MIPA 2 SMA Islam Sultan Agung 3 Semarang. Tujuan umum penelitian adalah mendeskripsikan kemampuan representasi matematis siswa kelas XI MIPA 2 SMA Islam Sultan Agung 3 Semarang. Sedangkan tujuan khusus penelitian adalah mendeskripsikan kemapuan representasi visual, simbolik, dan verbal dalam menyelesaikan soal program linear. Program Linear merupakan salah satu materi yang dipelajari oleh siswa kelas XI SMA. Aplikasi materi tersebut dapat berupa persoalan sehari-hari, sehingga memerlukan kemampuan representasi yang baik dalam menyelesaikan permasalahan yang diberikan.

\section{METODE PENELITIAN}

Metode yang digunakan dalam penelitian ini adalah metode deskriptif. Karena penelitian ini bertujuan memperoleh data dan informasi secara mendalam mengenai kemampuan representasi siswa dalam menyelesaikan soal program linear, maka bentuk penelitian yang dianggap sesuai adalah penelitian kualitatif.

Subjek penelitian ini adalah seluruh siswa kelas XI MIPA 2 SMA Islam Sultan Agung 3 Semarang tahun pelajaran 2019/2020. Sebagaimana yang dikatakan Galton (Ruseffendi, 1991) bahwa kemampuan siswa akan menyebar secara normal, yakni terdapat kategori yang rendah, sedang dan baik secara relatif. Dengan demikian, subjek yang diteliti dalam penelitian ini dapat mewakili tiga kategori kemampuan siswa, yakni rendah, sedang, dan tinggi. Instrument yang digunakan adalah tes uraian representasi matematis dan teknik pengumpulan data dalam penelitian ini adalah observasi dan tes. Observasi digunakan untuk memperoleh informasi tentang pelaksanaan proses pembelajaran pada saat pembelajaran. Tes digunakan untuk memperoleh data representasi siswa dalam menyelesaikan soal program linear.

Alasan memilih tes uraian adalah memudahkan dalam melihat representasi siswa yang digunakan dalam menyelesaikan soal tersebut. Analisis data untuk mengetahui bagaimana representasi siswa menggunakan analisis deskriptif. Perolehan data untuk mengukur 
kemampuan representasi matematis, maka dilakukan berdasarkan pedoman penskoran.

\section{HASIL DAN PEMBAHASAN}

Tes kemampuan representasi matematis siswa yang diberikan berjumlah 2 soal yang dibuat dalam bentuk uraian. Setelah memberikan tes tertulis mengenai kemampuan representasi matematis kepada 19 siswa kelas XI MIPA 2 SMA Islam Sultan Agung 3 Semarang, tes tersebut kemudian diberikan skor sesuai dengan kriteria penskoran yang tercantum dalam Tabel 2. Selanjutnya diberikan persentase dari skor yang didapat dan dianalisis. Berikut akan disajikan hasil tes kemampuan representasi matematis siswa.

Tabel 2. Hasil Tes Kemampuan Representasi Matematis

\begin{tabular}{|c|c|c|c|c|c|}
\hline & & Skor & $\begin{array}{c}\text { Skor } \\
\text { Maks } \\
\text {. }\end{array}$ & $\begin{array}{c}\text { Presentas } \\
\text { e } \\
\%\end{array}$ & Kategori \\
\hline Skor Tes & Visual & 97 & 114 & 85,08 & Tinggi \\
\hline $\begin{array}{l}\text { Kemampuan } \\
\text { Representasi }\end{array}$ & Simbolik & 104 & 114 & 91,27 & $\begin{array}{l}\text { Sangat } \\
\text { tinggi }\end{array}$ \\
\hline Matematis & Verbal & 77 & 114 & 67,54 & Sedang \\
\hline Skor & & 278 & 342 & 81,28 & Tinggi \\
\hline
\end{tabular}

Berdasarkan Tabel 3, skor yang diperoleh siswa pada indikator representasi visual berupa tabel maupun gambar adalah 97 dengan presentase $85,08 \%$ sehingga kategori representasi visual berupa tabel maupun gambar adalah tinggi. Skor yang diperoleh siswa pada indikator representasi simbolik berupa model matematika adalah 104 dengan presentase $91,27 \%$ sehingga kategori representasi simbolik berupa model matematika adalah sangat tinggi. Skor yang diperoleh siswa pada indikator representasi verbal berupa menyelesaikan masalah menggunakan kata-kata adalah 77 dengan presentase $67,54 \%$ sehingga kategori representasi verbal adalah sedang. Dari ketiga representasi diatas maka jumlah skornya 278 dengan presentase $81,28 \%$ sehingga seluruh representasi yang di tes kan maka siswa kelas XI MIPA 2 SMA Islam Sultan Agung 3 Semarang memiliki representasi tinggi.

Berdasarkan hasil data yang diperoleh kemampuan representasi siswa secara keseluruhan, dibawah ini akan dikaji pembahasan mengenai kemampuan representasi matematis siswa pada tiap representasi.

1. Representasi Visual Berupa Tabel maupun Gambar

Pada soal nomor 1 dan 2, skor yang diperoleh siswa pada indikator representasi visual berupa tabel maupun gambar adalah 97 dengan presentase 85,08 \%. Hal ini menunjukkan bahwa kemampuan representasi visual tegolong dalam kategori tinggi. 
Pada langkah penyelesaian, hanya beberapa siswa yang menggunakan tabel untuk menentukan titik potong. Siswa yang lainnya tidak menggunakan tabel, langsung menggambarnya dalam koordinat kartesius untuk mengetahui daerah penyelesaian.
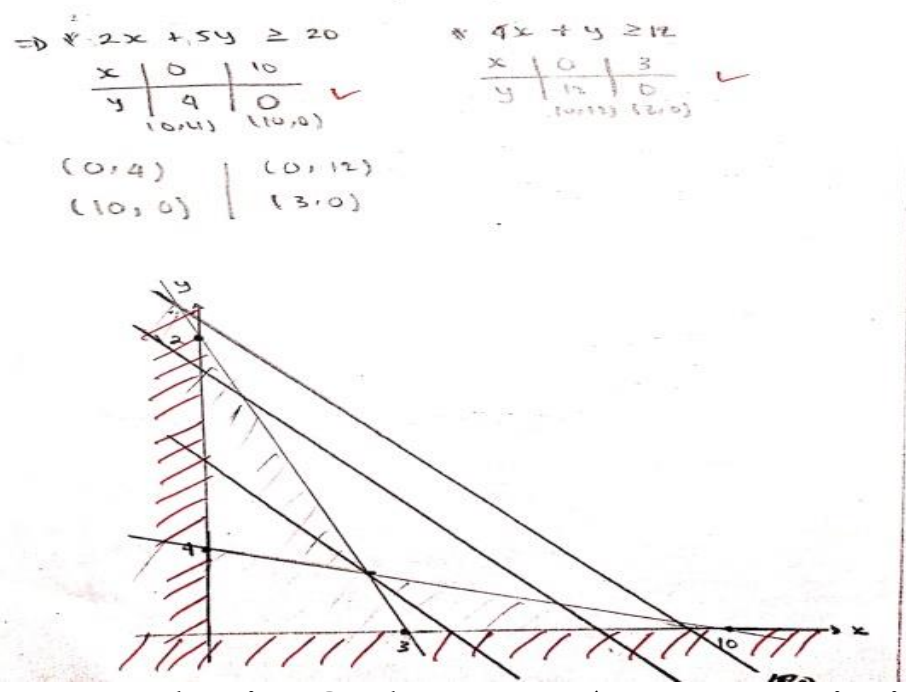

\section{Gambar 1. Penyelesaian Soal Nomor 1 (Representasi Visual)}

Penyelesaian pada gambar 1 yang diselesaikan oleh MRS merupakan contoh jawaban benar dan jelas karena dalam menyelesaikan soal menggunakan tabel terlebih dahulu untuk menentukan titik potong kemudian digambarkan kedalam bentuk koordinat kartesius.

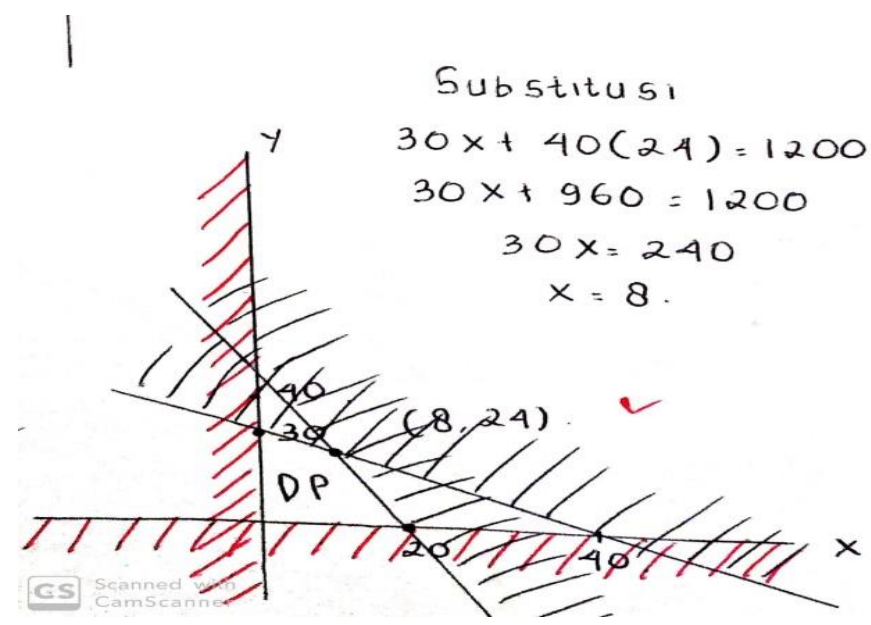

\section{Gambar 2. Penyelesaian Soal Nomor 2 (Representasi Visual)}

Penyelesaian pada gambar 2 yang diselesaikan oleh AAS sudah benar namun kurang jelas dalam menentukan titik potong, karena tidak ada tabel yang digunakan dalam mencari titik potong. AA langsung menggambarnya ke dalam koordinat kartesius untuk mencari daerah penyelesaian. 
2. Representasi Simbolik Berupa Persamaan dan Model Matematika

Pada soal nomor 1 dan 2, skor yang diperoleh siswa pada indikator representasi simbolik berupa model matematika adalah 104 dengan presentase $91,27 \%$. Hal ini menunjukkan bahwa kemampuan representasi simbolik berupa model matematika termasuk dalam kategori sangat tinggi.

Pada langkah pengerjaan, dapat disimpulkan pada representasi persamaan matematis berupa membuat persamaan untuk menentukan nilai $x$ dan y dengan menggunakan metode eliminasi dan substitusi dan model matematika. Kebanyakan siswa membuat permisalan dengan dengan variabel dan menuliskan fungsi tujuan, tetapi masih banyak siswa yang tidak membuat model matematika dengan lengkap.

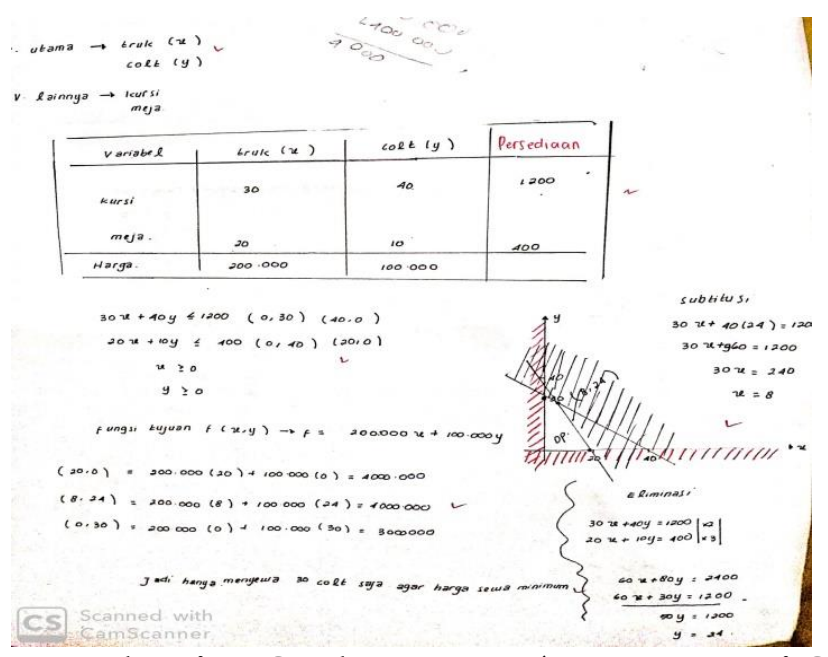

Gambar 3. Penyelesaian Soal Nomor 2 (Representasi Simbolik)

Berdasarkan penyelesaian pada gambar 3 yang diselesaikan oleh LDA jawaban sudah benar dan lengkap. Mulai dari membuat permisalan $x$ sebagai truk dan y sebagai colt kemudian membuat model matematika secara lengkap dari soal cerita yaitu menuliskan 30x $+40 y$ $\leq 1200,20 x+10 y \leq 400, x \geq 0, y \geq 0$ sampai dengan menuliskan fungsi tujuannya secara benar yaitu $f(x, y)=200000 x+100000 y$.

Walaupun sudah banyak siswa yang melakukan perhitungan secara teliti dan benar tetapi ada juga sebagian siswa yang masih kurang teliti dalam mengerjakan sehingga hasil akhirnya menjadi salah. Seperti yang terlihat pada gambar 4 berikut. 

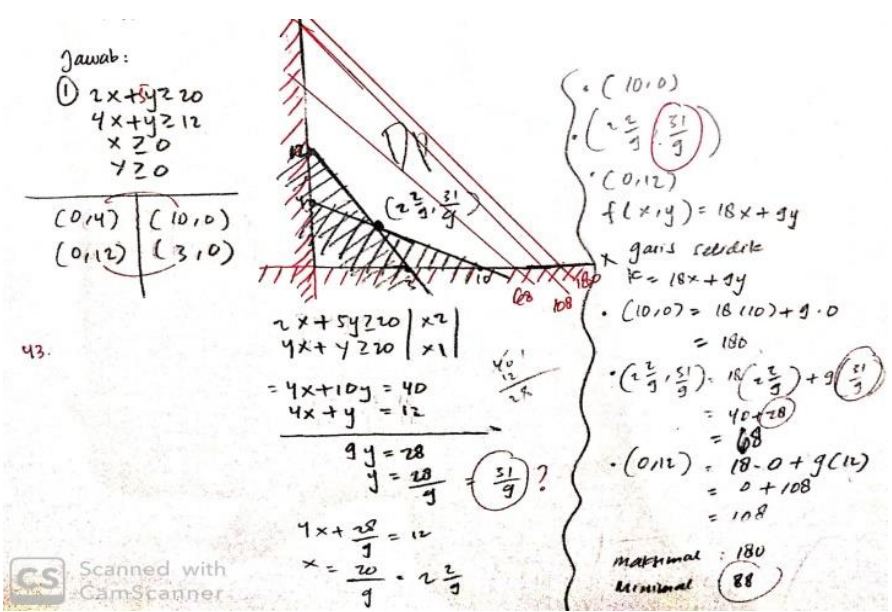

\section{Gambar 4. Penyelesaian Soal Nomor 1(Representasi Simbolik)}

Dari gambar diatas dapat kita lihat, IDN pada saat mencari nilai y tertulis $\frac{28}{9}$ tetapi oleh IDN diganti menjadi $\frac{21}{9}$, sehingga jawaban menjadi salah yang mengakibatkan dalam mencari titik potong pun akan salah juga begitu juga dalam mencari garis selidik. Kurang telitinya IDN dalam mengerjakan menjadikan jawaban menjadi salah padahal langkah-langkah dalam mengoperasikan metode eliminasi sudah benar.

3. Representasi Verbal Berupa Kata-Kata

Pada soal nomor 1 dan 2, skor yang diperoleh siswa pada indikator representasi verbal berupa kata-kata adalah 77 dengan presentase $67,54 \%$. Hal ini menunjukkan bahwa kemampuan representasi visual berupa kata-kata termasuk dalam kategori sedang. Dari langkah pengerjaan yang dilakukan oleh siswa hampir seluruh siswa tidak menuliskan langkah-langkah dalam menyelesaikan soal. Mereka hanya menggunakan kalimat verbal untuk kesimpulan jawaban saja, seperti terlihat dalam gambar berikut.

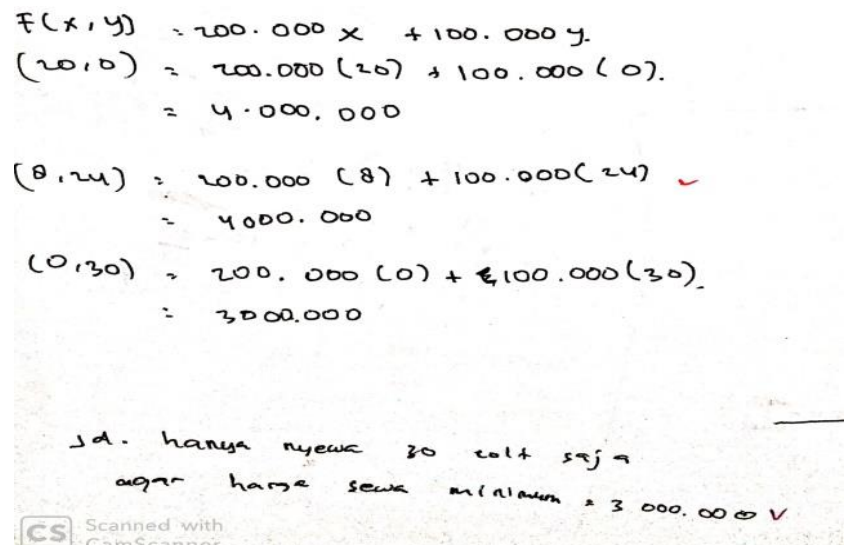

\section{Gambar 5. Penyelesaian Soal Nomor 1 (Representasi Verbal)}

Dari uraian diatas dapat disimpulkan bahwa pada penelitian ini untuk tiap-tiap bentuk representasi matematis didapat hasil yang 
berbeda, secara umum kemampuan representasi simbolik siswa dalam menyelesaikan soal matematika dapat dikategorikan sangat tinggi, kemampuan representasi visual siswa dalam menyelesaikan soal matematika dapat dikategorikan tinggi, dan kemampuan representasi verbal siswa dalam menyelesaikan soal matematika dapat dikategorikan sedang. Hal ini berarti dari ketiga kemampuan representasi matematis tersebut kemampuan representasi verbal yang paling sulit bagi siswa hal ini dibuktikan dari kesulitan siswa mendeskripsikan atau menjawab soal menggunakan kalimat verbal. Berdasarkan hasil analisis jawaban siswa adapun penyebab rendahnya kemampuan siswa dalam menginterpretasi suatu masalah matematis dengan kata-kata adalah rendahnya kemampuan menganalisis dan menerjemahkan suatu permasalahan ke dalam kalimat verbal.

\section{KESIMPULAN}

Berdasarkan hasil analisis data diperoleh kesimpulan yaitu kemampuan representasi visual siswa tergolong dalam kategori sedang dengan persentase sebesar 85,08 \%. Untuk persentase perolehan representasi simbolik sebesar $91,22 \%$ hal ini secara umum menunjukkan bahwa siswa sudah terampil membuat persamaan, model matematika atau representasi dari representasi lain yang diketahui, memecahkan masalah dengan menggunakan ekspresi matematika. Sedangkan untuk persentase representasi verbal sebesar 67,54\% menunjukkan bahwa kemampuan siswa memecahkan masalah ke dalam bentuk kata-kata tergolong tinggi. Pada penelitian ini terlihat bahwa pentingnya kemampuan representasi matematis dan dibutuhkan oleh siswa dalam memahami materi yang diberikan dan menyelesaikan soal, jika kemampuan representasi matematis kurang maka menyebabkan kurangnya pemahaman siswa dalam materi yang diberikan sehingga siswa susah memahami dan mengerjakan soal yang disediakan. Dari hasil penelitian ini diharapkan guru lebih memeperhatikan penyampaian materi dalam pembelajaran sehingga siswa akan menjadi lebih paham terhadap materi tersebut. Begitupun ketika siswa dihadapkan dengan soal latihan akan lebih memahami untuk menyelesaikan masalah tersebut.

\section{DAFTAR PUSTAKA}

Dahlan, J. A., \& Juandi, D. (2011). Analisis Representasi Matematik Siswa Sekolah Dasar Dalam Penyelesaian Masalah Matematika Kontekstual Jarnawi Afgani Dahlan \& Dadang Juandi Jurusan Pendidikan Matematika FPMIPA, Universitas Pendidikan Indonesia. Jurnal Pengajaran MIPA, 16, 128-138.

Fariz, I. N., Gusrayani, D., \& Isrok'atun. (2006). Pengaruh Pendekatan

Rme Terhadap Kemampuan Representasi Matematis Dan

Kepercayaan Diri Siswa. UPI Kampus Sumedang, (211), 751-760.

Fitriyah, I. (2014). Analisis Kemampuan Representasi Matematis Dalam 
Penyelesaian Soal Materi Segiempat Kelas VII SMP N 1 Gubug Kabuoaten Grobogan.

Hijriani, L., Rahardjo, S., \& Rahardi, R. (2018). Deskripsi Representasi Matematis Siswa SMP dalam Menyelesaikan Soal PISA. Jurnal Pendidikan, 3, 603-607.

Huda, U., Musdi, E., \& Nari, N. (2019). Analisis Kemampuan Representasi Matematis Siswa dalam Menyelesaikan Soal Pemecahan Masalah Matematika. Jurnal Ta'dib, 22(1).

Kholiqowati, H., Sugiarto, \& Hidayah, I. (2016). Analisis Kemampuan Representasi Matematis Ditinjau Dari Karakteristik Cara Berpikir Peserta Didik Dalam Pembelajaran Dengan Pendekatan Saintifik. Unnes Journal of Mathematics Education, 5(3).

Kusmaryono, I. (2016). Peranan representasi dan disposisi matematis siswa terhadap peningkatan mathematical power. 19-28.

Nelli, Yusmin, E., \& Sayu, S. (n.d.). Kemampuan Representasi Matematis Siswa Pada Materi Segi Empat Di Kelas VIII SMP KEMALA BHAYANGKARI. FKIP UNTAN Pontianak, 1-18.

Rahmawati, D., Hudiono, B., \& Nursangaji, A. (n.d.). Representasi visual matematika siswa dalam menyelesaikan masalah verbal spldv kelas ix smp. FKIP UNTAN Pontianak, 1-10.

Sulatri, Marwan, \& Duskri, M. (2017). Kemampuan representasi matematis siswa SMP melalui pendekatan pendidikan matematika realistik. 10(1), 5169.

Tyas, W. H., \& Sujadi, I. (2016). Representasi Matematis Siswa Dalam Menyelesaikan Masalah Matematika Pada Materi Aritmatika Sosial Dan Perbandingan Ditinjau Dari Gaya Kognitif Siswa Kelas VII SMP NEGERI 15 SURAKARTA Tahun Ajaran 2014 / 2015. 4(8), 781-792.

Ulandari, A. R. P., Hudiono, B., \& Bistari. (n.d.). Kemampuan representasi matematis menyelesaikan soal open-ended menurut tingkat kemampuan dasar materi segiempat di smp. (1), 1-10.

Villegas, J. L., Castro, E., \& Gutiérrez, J. (2009). Representations in problem solving : a case study with optimization problems 1. 7(17), 279-308.

Wijaya, C. B. (2018). Analisis Kemampuan Representasi Matematis Siswa Dalam Menyelesaikan Soal Lingkaran Pada Kelas VII-B Mts Assyafi' iyah Gondang. 4(2), 115-124. 